\title{
ANALISIS KEAKTIFAN BELAJAR SISWA MENGGUNAKAN MODEL PROJECT BASED LEARNING DENGAN PENDEKATAN STEM PADA PEMBELAJARAN FISIKA MATERI ELASTISITAS DI KELAS XI MIPA 5 SMA NEGERI 2 JEMBER
}

\author{
Nanda Rizky Fitrian Kanza ${ }^{1}$, Albertus Djoko Lesmono ${ }^{1}$, Heny Mulyo \\ Widodo $^{2}$ \\ ${ }^{1}$ Program Studi Pendidikan Fisika \\ ${ }^{2}$ SMA Negeri 2 Jember \\ Email:k4nza.nans@gmail.com
}

\begin{abstract}
This research describes the subject of elasticity using the Project Based Learning (PJBL) model with the STEM approach to improve students activeness. This research implemented for XI MIPA 5 class at 2 Jember Senior High School in the 2019/2020 academic year during August until September 2019. Data were collected through observation and interviews. This data were analyzed descriptively. The results showed that the Project Based Learning model with the STEM (Sains, Technology, Engineering, and Mathematics) approach could increase of students activeness for XI MIPA 5 class at 2 Jember Senior High School of elasticity material.
\end{abstract}

Keywords: Elasticity, Students Activeness, Project Based Learning, STEM.

\section{PENDAHULUAN}

Pendidikan merupakan salah satu aspek penting dalam kehidupan manusia. Kualitas pendidikan yang sangat tinggi diperlukan untuk mendukung terciptanya manusia yang cerdas dan berkualitas serta mampu bersaing di era globalisasi. Pendidikan memiliki peranan dalam pembentukan karakter, perkembangan ilmu, dan mental seorang anak yang nantiya akan tumbuh menjadi seorang manusia dewasa yang akan memberikan pengaruh terhadap lingkungannya.

Pendidikan diharapkan mampu memelihara dan meningkatkan ilmu pengetahuan agar dapat membentuk peserta didik dalam kecerdasannya. Dalam mencapai tujuan pendidikan tersebut, diperlukan kerjasama antara guru dan siswa. Selama ini, proses pembelajaran masih terpusat pada guru saja. Penggunaan metode ceramah menjadi pilihan bagi guru tanpa adanya suatu inovasi, sehingga siswa menjadi bosan dan cenderung pasif. Hal ini 
menimbulkan keaktifan siswa yang rendah.

Keaktifan merupakan kegiatan yang dapat bersifat fisik maupun mental. Belajar harus melalui berbagai macam aktifitas. Keaktifan siswa dalam kegiatan belajar adalah untuk menekankan pemahaman atas persoalan atau segala sesuatu yang mereka hadapi dalam proses pembelajaran. Keaktifan belajar siswa merupakan unsur dasar yang penting dalam keberhasilan dalam pembelajaran. Menurut Kamus Besar Bahasa Indonesia, keaktifan berasal dari kata dasar aktif yang memiliki arti giat. Keaktifan belajar adalah proses kegiatan belajar mengajar yang subjek didiknya secara intelektual dan emosional sehingga siswa mampu berpartisipasi secara aktif dalam melakukan kegiatan belajar (Sudjana, 2010). Sehingga, keaktifan belajar siswa merupakan suatu proses kegiatan belajar mengajar yang menuntut siswa untuk ikut terlibat secara aktif dalam proses pembelajaran dan membuat tingkah laku siswa menjadi lebih baik. Keaktifan belajar siswa diamati ketika proses pembelajaran berlangsung dalam aktivitas siswa. Keaktifan dalam belajar fisika terletak pada dua segi, yaitu aktif dalam bertindak (hands activity) dan aktif berpikir (minds activity) (NRC, 1996). Siswa akan menjadi aktif ketika siswa tersebut dapat menghubungkan antara pengetahuan baru dengan pemahaman awal mereka. Namun, dalam pelaksanaannya menghubungkan antara keduanya dalam pembelajaran fisika tidak mudah. Tujuan dari pembelajaran fisika untuk mengembangkan pengetahuan, pemahaman, dan kemampuan analisis siswa terhadap lingkungan dan sekitarnya (Alifa, 2018). Sebuah pembelajaran yang berfokus untuk memenuhi tujuan tersebut berarti harus pembelajaran yang membawa pelajaran sesuai dengan keadaan sehari-hari (Fox, 2006: Schwartz \& Crawford, 2006).

Dalam proses pembelajaran, siswa dituntut agar berperan aktif salah satunya pada kegiatan penemuan, sedangkan guru yang semula bertindak sebagai sumber belajar beralih fungsi menjadi seorang fasilitator kegiatan pembelajaran yang membimbing siswa untuk memecahkan permasalahan yang dihadapi dalam belajar (Mendikbud, 2013). Kenyataannya, masih ada beberapa 
guru yang belum bisa menerapkan pembelajaran seperti itu. Masih ada guru yang hanya menyajikan materi secara teoritik dan siswa yang pasif hanya mendengarkan ceramah guru. Hal ini menyebabkan pembelajaran menjadi tidak menyenangkan dan siswa tidak dapat mengeksplorasi pengetahuan dan keaktifan siswa yang terbatas.

Strategi belajar yang tepat untuk melibatkan siswa dalam proses pembelajaran secara aktif salah satunya menggunakan model pembelajaran Project Based Learning (PjBL). Model PjBL adalah model pembelajaran yang dapat mendorong siswa untuk aktif belajar secara berkolaborasi untuk memecahkan masalah sehingga dapat mengkonstruksi inti pelajaran dari temuan-temuan dalam tugas atau proyek yang dilakukan. Model ini digunakan untuk melatih siswa melakukan analisis terhadap permasalahan, kemudian melakukan eksplorasi, mengumpulkan informasi, interpretasi, dan penilaian dalam mengerjakan proyek yang terkait dengan permasalahan yang dikaji.
Dalam pembelajaran STEM peserta didik tidak hanya mendapatkan materinya saja tetapi ada praktik lebih memudahkan peserta didik dalam proses pembelajaran. Hasil Penelitian yang dilakukan Irma Rahma Suwarma, Puji Astuti, Endah Nur Endah pada tahun 2015, menunjukkan bahwa pembelajaran berbasis STEM ini mampu meningkatkan motivasi dan keaktifan siswa dalam proses pembelajaran.

Dari uraian di atas, maka perlu adanya strategi pembelajaran yang diharapkan dapat meningkatkan keaktifan siswa. Salah satu strategi agar siswa menjadi lebih aktif dalam proses pembelajaran adalah dengan menggunakan model yang tepat. Model pembelajaran untuk mengatasi hal tersebut adalah dengan menggunakan PjBL dengan pendekatan STEM (Sains, Technology, Engineering, and Mathematics).

\section{METODE}

Penelitian ini menggunakan pendekatan kualitatif. Data yang dikumpulkan dalam penelitian ini akan dianalisis secara deskriptif. 
Penelitian ini mendeskripsikan pembelajaran dengan pokok bahasan elastisitas menggunakan model pembelajaran $\mathrm{PjBL}$ dengan pendekatan STEM (Sains, Technology, Engineering, and Mathematics) untuk meningkatkan keaktifan belajar siswa. Sumber data diperoleh dari siswa kelas XI MIPA 5 di SMA Negeri 2 Jember.

Pengumpulan data dilakukan dengan observasi dan wawancara. Analisis data keaktifan belajar dengan cara data keaktifan belajar siswa yang telah diperoleh, dinilai menggunakan kriteria penskoran keaktifan belajar siswa agar dapat diketahui skor keaktifan belajar siswa. Setelah skor keaktifan belajar siswa tersebut diperoleh, langkah selanjutnya melakukan pengolahan data dengan memasukkan skor keaktifan belajar siswa pada skala keaktifan siswa, agar dapat diketahui skala keaktifan belajar siswa pada tiap tindakan yang kemudian disajikan pada deskriptif data. Keaktifan belajar siswa diobservasi dengan lembar keaktifan belajar siswa yang berisi indikator keaktifan yang harus dicapai siswa. Penilaian pada lembar observasi ini dengan menentukan presentase keaktifan setiap siswa. Presentase keaktifan siswa (PKS) diperoleh dari

PKS

$\frac{\text { Jumlah indikator yang terpenuhi }}{\text { Jumlah indikator keselurwhan }} x 100 \%$

Tabel 1 Kriteria Keaktifan Siswa

\begin{tabular}{|c|c|}
\hline Persentase & Kategori \\
\hline $75 \%<$ skor $\leq 100 \%$ & Sangat baik \\
\hline $50 \%<$ skor $\leq 75 \%$ & Baik \\
\hline $25 \%<$ skor $\leq 50 \%$ & Cukup \\
\hline $0 \leq$ skor $\leq 25 \%$ & Kurang \\
\hline \multicolumn{2}{|l|}{ (Utami, 2011) } \\
\hline \multicolumn{2}{|c|}{ Indikator keaktifan yang harus } \\
\hline \multicolumn{2}{|c|}{$\begin{array}{l}\text { dicapai siswa antara lain 1) } \\
\text { memperhatikan dan mendengarkan }\end{array}$} \\
\hline \multicolumn{2}{|c|}{ penjelasan guru, 2) menjawab } \\
\hline \multirow{2}{*}{\multicolumn{2}{|c|}{$\begin{array}{l}\text { pertanyaan guru, 3) mengajukan } \\
\text { pertanyaan kepada guru dan siswa }\end{array}$}} \\
\hline & \\
\hline \multicolumn{2}{|c|}{ lain, 4) mencatat penjelasan guru dan } \\
\hline \multicolumn{2}{|c|}{ hasil diskusi, 5) membaca materi, 6) } \\
\hline \multicolumn{2}{|c|}{ memberikan pendapat ketika diskusi, } \\
\hline \multicolumn{2}{|c|}{ 7) mendengarkan pendapat teman, 8) } \\
\hline \multirow{2}{*}{\multicolumn{2}{|c|}{$\begin{array}{l}\text { memberikan tanggapan, 9) berlatih } \\
\text { menyelesaikan latihan soal, 10) }\end{array}$}} \\
\hline & \\
\hline berani mempresent & ikan hasil \\
\hline diskusi. & \\
\hline
\end{tabular}




\section{HASIL DAN PEMBAHASAN}

Penelitian ini menggunakan lembar observasi dan wawancara untuk mengukur tingkat keaktifan belajar siswa pada materi elastisitas di kelas XI MIPA 5 SMA Negeri 2 Jember. Keseluruhan yang mengikuti kegiatan pembelajaran sebanyak 36 siswa. Indikator keaktifan belajar yang harus dicapai siswa antara lain memperhatikan dan mendengarkan penjelasan guru, menjawab pertanyaan guru, mengajukan pertanyaan kepada guru dan siswa lain, mencatat penjelasan guru dan hasil diskusi, membaca materi, memberikan pendapat ketika diskusi, mendengarkan pendapat teman, memberikan tanggapan, berlatih menyelesaikan latihan soal, dan berani mempresentasikan hasil diskusi.

Dari data yang diperoleh, kemudian dianalisis berdasarkan indikator tersebut. Berdasarkan hasil analisis yang dilakukan bahwa pada indikator 1 sebanyak 34 siswa memperhatikan dan mendengarkan penjelasan guru selama proses pembelajaran, pada indikator 2 terdapat 19 siswa yang menjawab pertanyaan guru saat di kelas, pada indikator 3 ada 32 siswa yang bertanya kepada guru dan siswa lain, pada indikator 4 sebanyak 36 siswa atau semua siswa di kelas XI MIPA 5 mencatat penjelasan guru dan hasil diskusi yang dilakukan selama pembelajaran, pada indikator 5 ada 34 siswa yang membaca materi, pada indikator 6 ada 32 siswa yang memberikan pendapat ketika berdiskusi, pada indikator 7 ada 36 siswa mendengarkan pendapat teman saat berdiskusi dan pada saat pembelajaran berlangsung, pada indikator 8 sebanyak 29 siswa memberikan tanggapan saat proses pembelajaran berlangsung, pada indikator 9 ada 36 siswa yang berlatih menyelesaikan soal, dan pada indikator 10 sebanyak 36 siswa berani mempresentasikan hasil diskusi.

Berdasarkan hasil analisis keaktifan belajar siswa dengan 10 indikator untuk setiap siswanya, bahwa terdapat 19 siswa dengan persentase $100 \%$ termasuk dalam kategori sangat baik, kemudian 10 siswa dengan persentase $90 \%$ termasuk dalam kategori sangat baik, 
1 siswa dengan persentase $80 \%$ termasuk dalam kategori sangat baik, 4 siswa dengan persentase $70 \%$ termasuk dalam kategori baik, kemudian 1 siswa dengan persentase $60 \%$ termasuk dalam kategori baik, dan 1 siswa dengan persentase $50 \%$ termasuk dalam kategori cukup. Sehingga, hasil observasi dan wawancara keaktifan belajar siswa pada pembelajaran fisika menggunakan model pembelajaran PjBL dengan pendekatan STEM dapat dikategorikan terdapat 30 siswa yang memiliki keaktifan belajar sangat baik, 5 siswa memiliki keaktifan belajar yang baik, dan 1 siswa yang memiliki keaktifan belajar cukup.

Selain itu, hasil wawancara yang dilakukan dengan beberapa siswa di kelas XI MIPA 5 menyatakan bahwa siswa lebih antusias dalam kegiatan pembelajaran menggunakan model pembelajaran Project Based Learning (PjBL) dengan pendekatan STEM dibandingkan dengan model pembelajaran konvensional. Saat kegiatan pembelajaran menggunakan model konvensional berlangsung, siswa lebih banyak mendengarkan guru menyampaikan materi. Berbeda saat kegiatan pembelajaran menggunakan model PjBL dengan pendekatan STEM ini, siswa diajak untuk berperan aktif dan siswa merasa lebih senang serta langsung mengetahui penerapannya dalam kehidupan sehari-hari.

Dari hal tersebut, menunjukkan bahwa saat proses pembelajaran menggunakan model Project Based Learning dengan pendekatan STEM di kelas XI MIPA 5 pada materi elastisitas dapat meningkatkan keaktifan belajar siswa.

\section{SIMPULAN DAN SARAN}

Berdasarkan hasil penelitian menunjukkan bahwa penerapan model pembelajaran Project Based Learning dengan pendekatan STEM (Sains, Technology, Engineering, and Mathematics) mampu meningkatkan keaktifan belajar siswa kelas XI MIPA 5 SMA Negeri 2 Jember Kabupaten Jember pada materi elastisitas. Guru dapat menerapkan model pembelajaran Project Based Learning dengan pendekatan STEM untuk 
meningkatkan keaktifan belajar siswa dalam proses pembelajaran.

Saran yang dapat diberikan berdasarkan hasil penelitian antara lain guru harus lebih memotivasi seluruh siswa untuk selalu terlibat aktif dalam proses pembelajaran, guru harus lebih tegas saat melakukan proses pembelajaran, alokasi waktu harus disesuaikan dengan Rencana Pelaksanaan Pembelajaran (RPP) terutama pada saat pembuatan prototype dan kegiatan presentasi berkelompok, bagi peneliti selanjutnya, model pembelajaran Project Based Learning (PjBL) dengan pendekatan STEM dapat diterapkan pada materi elastisitas, yakni dengan mengimplementasikan permasalahan yang ada di kehidupan sehari-hari.

\section{DAFTAR PUSTAKA}

Alifa, D.M., F. Azzahroh., I.R. Pangestu. 2018. Penerapan Metode STEM (Science, Technology, Engineering, and Mathematics) berbasis Proyek untuk Meningkatkan Kreativitas Siswa SMA Kelas XI pada Materi Gas Ideal. Prosiding Seminar Nasional Pendidikan Sains (SNPS 2018). 27 Oktober 2018. SNIPS: 88-109.
Roestiyah, N.K. 2008. Strategi Pembelajaran. Jakarta: Rineka Cipta.

Schwartz, R.S., \& Crawford, B.A. 2006. Authentic Scientific Inquiry as Context for Teaching Nature of Science: Identifying critical elements for success. Dordrecht: Springer.

Segala, S. 2010. Konsep dan Makna Pembelajaran. Bandung: Alfabeta.

Sudjana, N. 2010. Dasar-dasar Proses Pembelajaran. Bandung: Sinar Baru.

Sugiyono. 2014. Metode Penelitian Kuantitatif, Kualitatif, dan $R D$. Bandung: Alfabeta.

Suryosubroto, B. 2009. Proses Belajar Mengajar di Sekolah. Jakarta: Rineka Cipta.

Zaeni, Johara A. 2016. Analisis Keaktifan Siswa Melalui Penerapan Model Teams Gamestournaments (TGT) pada Materi Termokimia Kelas XI IPA 5 di SMA N 15 Semarang. Seminar Nasional Pendidikan, Sains, dan Teknologi FMIPA Universitas Muhammadiyah Semarang. ISBN: 978-662-61599-6-0. Hal 416-425. 